\title{
Економіка підприємства
}

UDC: $006: 67+338$

JEL Classification: L15, L60, M11, O120

\author{
Danyil Zmitrovych \\ ORCID ID: 0000-0003-1636-0919
}

Anna Kukharuk

PhD, Associate Professor

ORCID ID: 0000-0002-2792-4137

National Technical University of Ukraine "Igor Sikorsky Kyiv Polytechnic Institute"

\section{STANDARDIZATION AS A TOOL TO IMPACT THE INTERNATIONAL COMPETITIVENESS OF MANUFACTURING ENTERPRISES}

\section{СТАНДАРТИЗАЦІЯ ЯК ІНСТРУМЕНТ ВПЛИВУ НА МІЖНАРОДНУ КОНКУРЕНТОСПРОМОЖНІСТЬ ВИРОБНИЧИХ ПІДПРИЕМСТВ}

The article is devoted to the study of the possibilities of manufacturing enterprises to intensify export activity and ensure international competitiveness through such a tool as standardization. The problem of increasing the international competitiveness of domestic manufacturing enterprises in various industries is of particular importance. Increased attention of scientists and practitioners to this issue is due to a few reasons. First, in the face of growing uncertainty due to the global Covid-19 pandemic, companies must adapt to the new requirements for their activities by foreign partners. Secondly, today the increase in the capacity of the national economy of Ukraine is possible largely due to its openness and scientific and technical cooperation with other countries, for which it is necessary to ensure the highly competitive potential of Ukrainian industrial enterprises. The article provides an analysis of the dynamics of industrial production in Ukraine in recent years. By comparative analysis of the dynamics of the number of economic entities and the volume of manufactured and sold industrial products in Ukraine, the authors conclude about the possible recovery of domestic industry and its development. The authors give examples of obtaining additional opportunities for export by specific domestic manufacturing enterprises through their implementation of international standards. The authors argue about the relationship between standardization and the process of increasing the international competitiveness of manufacturing enterprises and schematically summarize this relationship. A promising area of further research is to assess the level of economic efficiency of standardization as a tool to increase the international competitiveness of manufacturing enterprises in the recovery of the world economy after the Covid-19 pandemic.

Keywords: international competitiveness, manufacturing enterprise, export activity, standardization, ISO standards.

Статтю присвячено дослідженню можливостей виробничих підприємств щзодо інтенсифікації експортної активності та забезпеченні міжнародної 
конкурентоспроможності за рахунок такого інструменту, як стандартизащія. Проблема підвищення міжнародної конкурентоспроможності вітчизняних виробничих підприємств різних галузей промисловості набуває особливого значення. Посилена увага вчених та практиків до даного питання зумовлена низкою причин. По-перше, в умовах зростання невизначеності через світову пандемію Covid-19 підприємства мають адаптуватися до нових вимог щуодо їх діяльності з боку іноземних партнерів. По-друге, сьогодні нарощення потужності національної економіки України можливе більшою мірою внаслідок ї̈ відкритості та науково-технічної співпраці з іншими країнами, для чого необхідно забезпечити високий конкурентний потенціал українських промислових підприємств. У статті наводиться аналіз динаміки промислового виробництва в Украйні за останні роки. Шляхом порівняльного аналізу динаміки кількості суб'єктів господарювання та обсягів виготовленої та реалізованої промислової продукції в Украӥні, автори доходять висновку про можливе відновлення вітчизняної промисловості та ї̈ розвитку. Автори наводяться приклади отримання додаткових можливостей для експорту конкретними вітчизняними виробничими підприємствами через імплементацію ними міжнародних стандартів. Автори стверджують про наявність взаємозв'язку стандартизачії та процесу підвищення міжнародної конкурентоспроможності виробничих підприємств та схематично узагальнюють такий взаємозв'язок. Перспективним напрямком подальших досліджень $\epsilon$ оцінювання рівня економічної ефективності стандартизації як інструменту підвищення міжнародної конкурентоспроможності виробничих підприємств $у$ період відновлення світової економіки після пандемії Covid-19.

Ключові слова: міжнародна конкурентоспроможність, виробниче підприємство, експортна діяльність, стандартизація, ISO стандарти.

Introduction. At the present stage of economic development, the problem of increasing the international competitiveness of domestic manufacturing enterprises in various industries is of particular importance. The increased attention of scientists and practitioners to this issue is caused by several reasons. Firstly, in the face of growing uncertainty due to the global COVID-2019 pandemic, companies must adapt to the new requirements for their activities from foreign partners. Secondly, today the increase in the capacity of the national economy of Ukraine is possible largely because of its openness and scientific and technical cooperation with other countries, that is why it is necessary to ensure the high competitive potential of Ukrainian industrial enterprises.

One of the methods of ensuring a high level of competitiveness of the enterprise is the standardization of its activities. Developments on this issue are presented in the works of authors such as Byba V. and Tenytska N. [3] who investigated the quality of production as a factor of competitiveness of the enterprise, Yanovytska G. and Verhola U. [2], who highlighted the features of safety and quality provision of goods, works, services by the standardization as the main agent, Pochynok K. [4], summarizing that the standardization is one of the factors for providing the competitiveness of products, Arvius Ch. et al. [6], who made some prediction regarding the 
tools for competitive and innovative Europe, Naidonova M. [11], concretizing that all existing national and regional standards in Ukraine must be voluntary, and others.

Scientists have developed theoretical models of standardization for competitiveness. However, there is a need to study the economic results of the standardization, which domestic enterprises receive in international markets. For instance, it is important to study the impact of the implementation of international ISO standards on the ability of domestic enterprises to create and maintain competitive advantages in the international market.

Research objective. The purpose of the article is to analyze the impact of the standardization of enterprises on the formation of their competitiveness in international markets. The goal was achieved through the solution of the following tasks: to conduct the economic and statistical analysis of Ukrainian production enterprises activities; to consider examples of standardization of enterprises and to identify the obtained economic results; to generalize the impact of the standardization on the international competitiveness of domestic manufacturing enterprises.

Methodology. The following methods were used in the study: historical-logical, scientific concretization, generalization and comparison, statistical methods of analysis, as well as the method of graphic description.

Research results. It should be noted that the activity of enterprises depends entirely on other market participants, market size, and competition type. Analyzing the statistics [13] of Ukraine, we can conclude that the number of enterprises decrease every year (Fig. 1). Some enterprises cease operations, some of them participate in the processes of mergers and acquisitions.

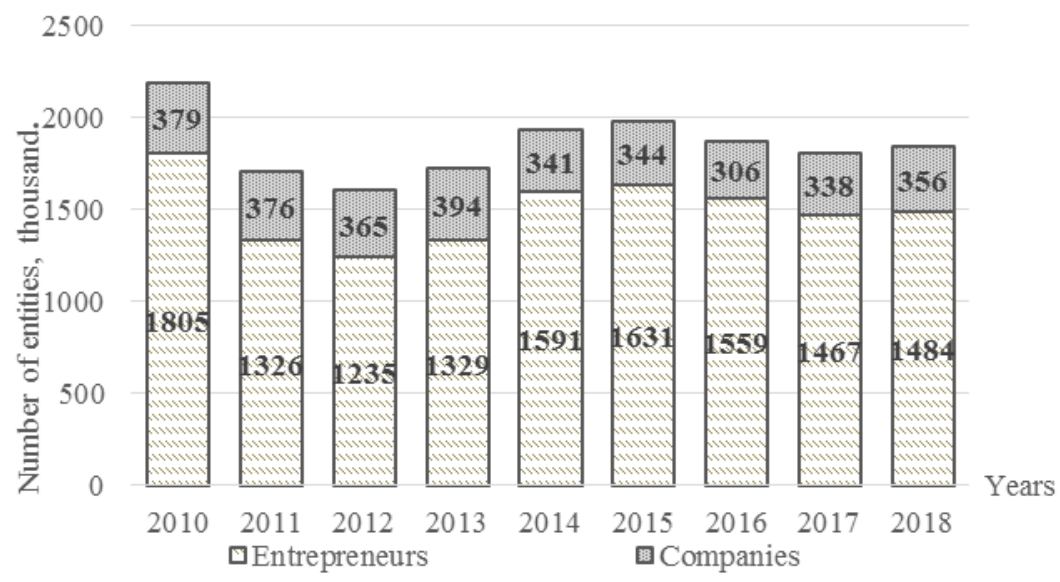

Figure 1 - Number of business entities in Ukraine, 2010-2018. Source: conducted on data [13] 
The downward trend is also observed for industrial enterprises: there are 4000 fewer industrial companies and 23000 fewer entrepreneurs in 2010 compared to 2018 (Fig. 2). However, this is only a quantitative fact.

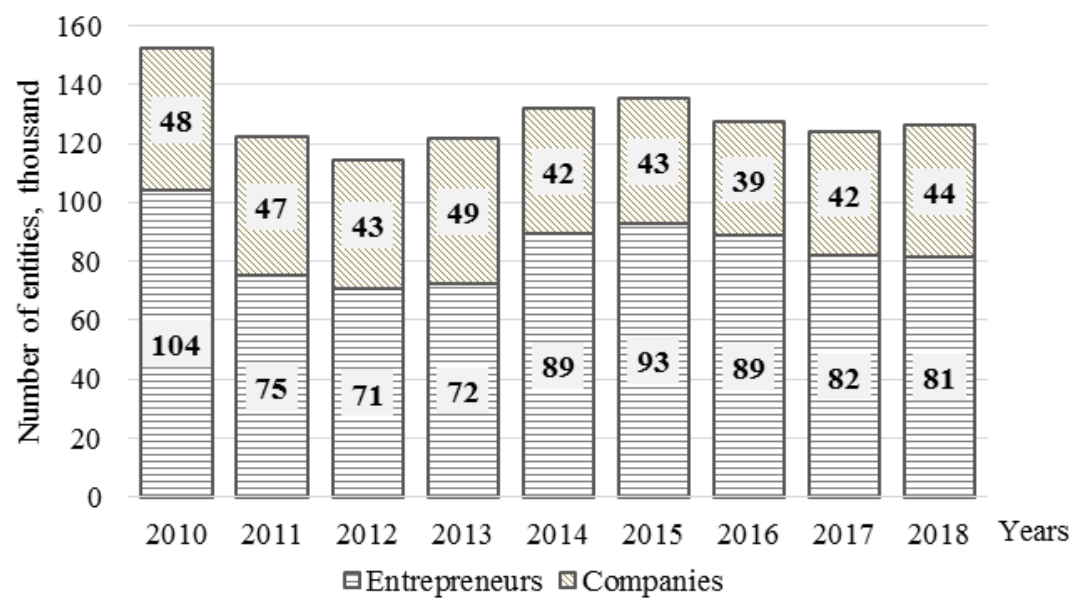

Figure 2 - Number of industrial enterprises in Ukraine, 2010-2018. Source: conducted on data [13]

At the same time, the analysis of the volumes of sold industrial products in Ukraine for the period 2010-2019 [14, 15] showed the following:

- increase in industrial production (Tab. 1);

- an average annual growth of more than UAH 200 billion and an increase in sales by 2.8 times in 2019 compared to 2010 .

Comparison of the mentioned values may indirectly indicate certain intensive development of industry in Ukraine. Moreover, in recent five years there has been a positive dynamic of exports in various directions (Fig. 3), except for the CIS countries (largely due to the aggravation of political and economic relations and the war with the Russian Federation).

The global COVID-2019 pandemic has led to a reduction in exports of goods from Ukraine. Exports of goods for the first five months of 2020 compared to the same period in 2019 decreased by 1.4 billion USD and amounted to 19.5 billion USD. The reduction in exports to foreign markets of food products and agricultural products by $2 \%$ (or 179 million USD) and mineral products by $4 \%$ (or 59 million USD). At the same time, supplies of metals and metal products decreased by 877 million USD, which was 19\% lower compared to the same period last year $[17$, p. 3]. Ukraine, like the rest of the world, has faced slowing economic growth and uncertainty. According to forecasts $[18$, p. 5], the recovery of world GDP is expected no earlier than the second half of 2021 . 
Table 1 - Indices of industrial production in Ukraine for 2015-2020 [15]

\begin{tabular}{|c|c|c|c|c|c|c|}
\hline \multirow{3}{*}{ Month } & \multicolumn{6}{|c|}{$\begin{array}{l}\text { Month (period) over the corresponding month (period) of the } \\
\text { previous year }\end{array}$} \\
\hline & \multirow{2}{*}{2020} & \multicolumn{5}{|c|}{ for reference: } \\
\hline & & 2019 & 2018 & 2017 & 2016 & 2015 \\
\hline January & 94,9 & 99,0 & 103,9 & 104,3 & 100,1 & 83,5 \\
\hline February & 98,5 & 98,3 & 105,2 & 96,6 & 108,2 & 83,5 \\
\hline January-February & 96,9 & 98,6 & 104,5 & 100,4 & 104,1 & 83,5 \\
\hline March & 92,3 & 102,4 & 104,3 & 100,9 & 103,1 & 82,7 \\
\hline January-March & 94,9 & 99,9 & 104,5 & 100,5 & 103,7 & 83,2 \\
\hline April & 83,8 & 104,3 & 105,5 & 97,1 & 104,2 & 83,3 \\
\hline January-April & 92,1 & 101,0 & 104,7 & 99,7 & 103,9 & 83,2 \\
\hline May & 87,8 & 103,3 & 103,5 & 103,5 & 101,1 & 83,7 \\
\hline January-May & 91,3 & 101,5 & 104,5 & 100,4 & 103,3 & 83,3 \\
\hline June & 94,4 & 100,6 & 102,3 & 106,0 & 98,1 & 85,3 \\
\hline January-June & 91,7 & 101,3 & 104,1 & 101,3 & 102,4 & 83,7 \\
\hline July & - & 101,7 & 104,1 & 101,0 & 101,4 & 86,8 \\
\hline January-July & - & 101,4 & 104,1 & 101,3 & 102,3 & 84,1 \\
\hline August & - & 101,2 & 100,8 & 102,9 & 105,2 & 92,6 \\
\hline January-August & - & 101,4 & 103,7 & 101,5 & 102,7 & 85,0 \\
\hline September & - & 100,4 & 101,5 & 100,9 & 105,0 & 93,5 \\
\hline $\begin{array}{l}\text { January- } \\
\text { September }\end{array}$ & - & 101,2 & 103,4 & 101,4 & 102,9 & 85,9 \\
\hline October & - & 97,1 & 102,7 & 101,3 & 105,1 & 92,9 \\
\hline January-October & - & 100,8 & 103,4 & 101,4 & 103,2 & 86,6 \\
\hline November & - & 94,1 & 101,9 & 100,5 & 108,7 & 91,4 \\
\hline $\begin{array}{l}\text { January- } \\
\text { November }\end{array}$ & - & 100,1 & 103,2 & 101,3 & 103,7 & 87,1 \\
\hline December & - & 93,3 & 101,1 & 99,4 & 106,6 & 94,9 \\
\hline $\begin{array}{l}\text { January- } \\
\text { December }\end{array}$ & - & 99,5 & 103,0 & 101,1 & 104,0 & 87,7 \\
\hline
\end{tabular}

Note: indices for 2015-2019 in Ukraine revised in connection with the change of the base year $(2016=100 \%)$.

${ }^{1}$ Data exclude the temporarily occupied territory of the Autonomous Republic of Crimea, the city of Sevastopol and a part of temporarily occupied territories in the Donetsk and Luhansk regions.

In the new conditions of uncertainty, domestic manufacturing enterprises should focus on increasing capacity and improving product quality to be able to continue economic activity in international markets after the recovery of the economies of partner countries. 


\section{0,0}

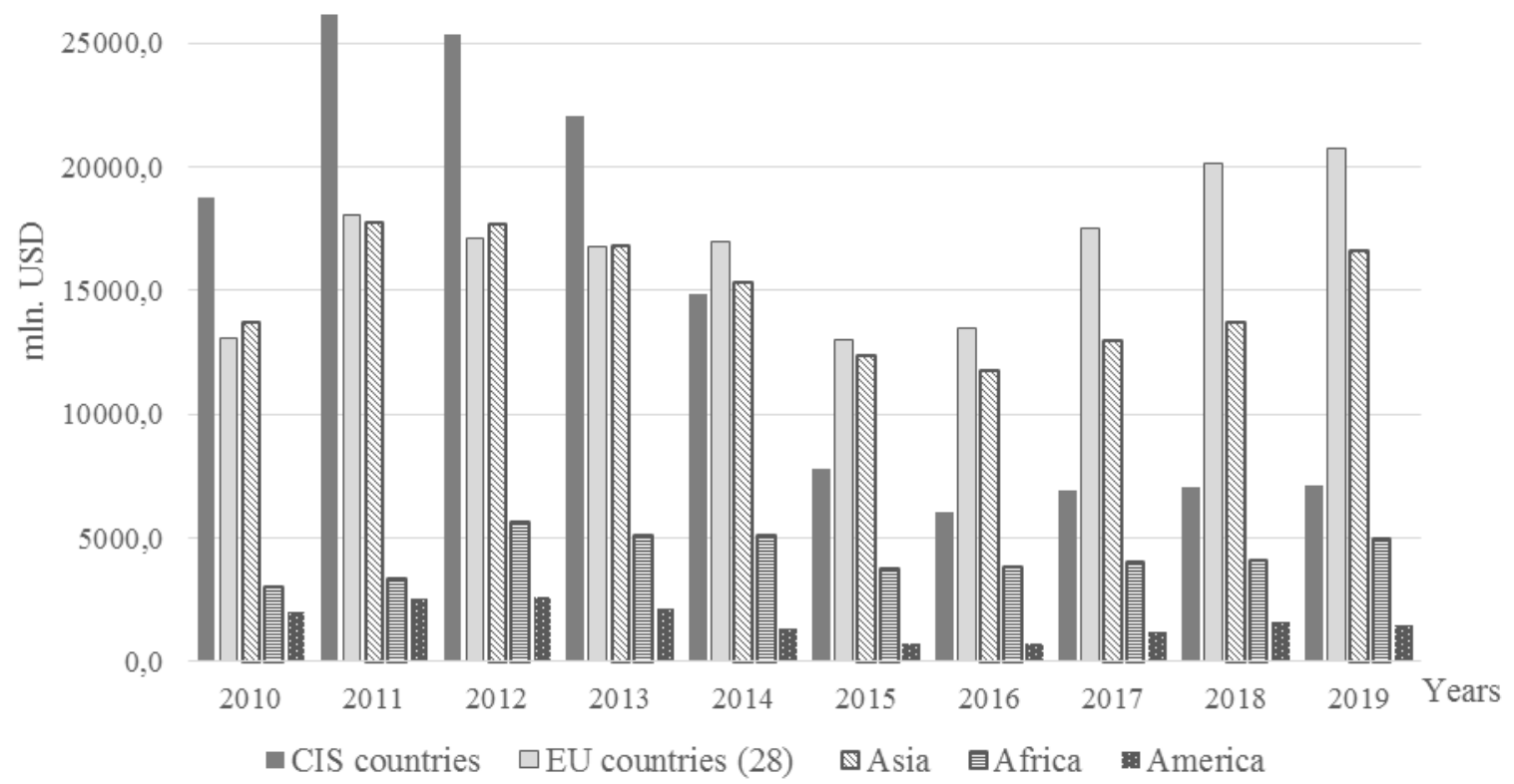

Figure 3 - Dynamics of the geographical structure of foreign trade in goods by Ukraine, 2010-2019

Source: conducted on data [13]

As it was noted by Dr. Nobuhiro Endo, President of the Japanese Industrial Standards Committee (JISC), "business is characterized by relentless change. Staying ahead of the competition, keeping up with technology and meeting customers' needs requires the agility and ability to evolve in real time. In order to face up to a rapidly evolving world, you need to have a system in place to adapt with the changes" [12, p. 2]. One of the tools for adapting to market changes is standardization and certification.

Due to the statistics provided by the official website of ISO [19], in 2018 the total number of enterprises with a certified quality management system was 1056855, including 513,742 entities from Asian countries (China works for export - engineering, textiles, non-ferrous metals, etc.). At the same time, in Ukraine, there are 2,037 enterprises certified according to the international standard ISO 9001 that indicates a low level of interest of producers in investing in the quality system.

A manufacturing company operating in the international market must ensure product quality control at all stages of production. First of all, it is not economically profitable for the company to receive any returns of defective products. Losses in monetary terms within Ukraine are much lower than losses in the case of returning exported products. Thus, the quality management system, as a tool of competitiveness, includes not only obtaining an international quality standard, it is primarily a guarantee of minimizing shortages in production. The number of allowable defects in the 
party is $1-3 \%$, depending on customer requirements. It is possible to ensure the number of defects on the line less than $1 \%$ only through constant control and modernization of production facilities.

Table 2 - Implementation of standards by Ukrainian production companies

\begin{tabular}{|c|c|c|c|}
\hline Enterprise & Industry & $\begin{array}{l}\text { Basic standards } \\
\text { implemented }\end{array}$ & Export \\
\hline Obolon & $\begin{array}{l}\text { Alcoholic and } \\
\text { soft drinks }\end{array}$ & $\begin{array}{l}\text { ISO 9001:2015 } \\
\text { ISO } 22000 \\
\text { ISO } 14001: 2015 \\
\text { OHSAS } 18 \\
\text { 001:2007 }\end{array}$ & $\begin{array}{l}\text { More than } 50 \text { countries. Export to } \\
\text { Belarus and Moldova. Exports to } \\
\text { Latin America and Asia }\end{array}$ \\
\hline Farmak & Pharmaceutics & $\begin{array}{l}\text { ISO } 9001 \\
\text { ISO } 13485 \\
\text { ISO } 22000\end{array}$ & $\begin{array}{l}\text { More than } 28 \text { countries, the total } \\
\text { share of exports of total sales is } \\
22.6 \%(2019), 1.417 \text { billion UAH. }\end{array}$ \\
\hline Danon & Food Industry & $\begin{array}{l}\text { FSSC } 22000 \\
\text { ISO } 9001: 2015 \\
\text { ISO } 22000 \\
\text { ISO } 10006 \\
\text { ISO 21500:2012 }\end{array}$ & $\begin{array}{l}\text { After receiving the FSSC } 22000 \\
\text { certificate, a company began } \\
\text { exporting dairy products to Europe. }\end{array}$ \\
\hline Arterium & Pharmaceutics & $\begin{array}{l}\text { ISO 9001:2015 } \\
\text { ISO } 22000 \\
\text { GMP }\end{array}$ & $\begin{array}{l}\text { Exports to CIS countries and Eastern } \\
\text { European countries }\end{array}$ \\
\hline Elfa & Cosmetics & $\begin{array}{l}\text { ISO 9001:2015 } \\
\text { ISO } 22000 \\
\text { GMP } \\
\text { ISO 22716:2007 }\end{array}$ & $\begin{array}{l}\text { Exports to more than } 20 \text { countries, } \\
\text { one of the leaders of Ukrainian } \\
\text { manufacturers for export. }\end{array}$ \\
\hline
\end{tabular}

Source: conducted based on [20-25].

After analyzing open sources [20-25] with the statistics and history of international activities of companies, it was concluded that before entering 
the international market or expanding international activities, each company has certified production according to one of the standards of quality or environmental safety (Fig. 4).
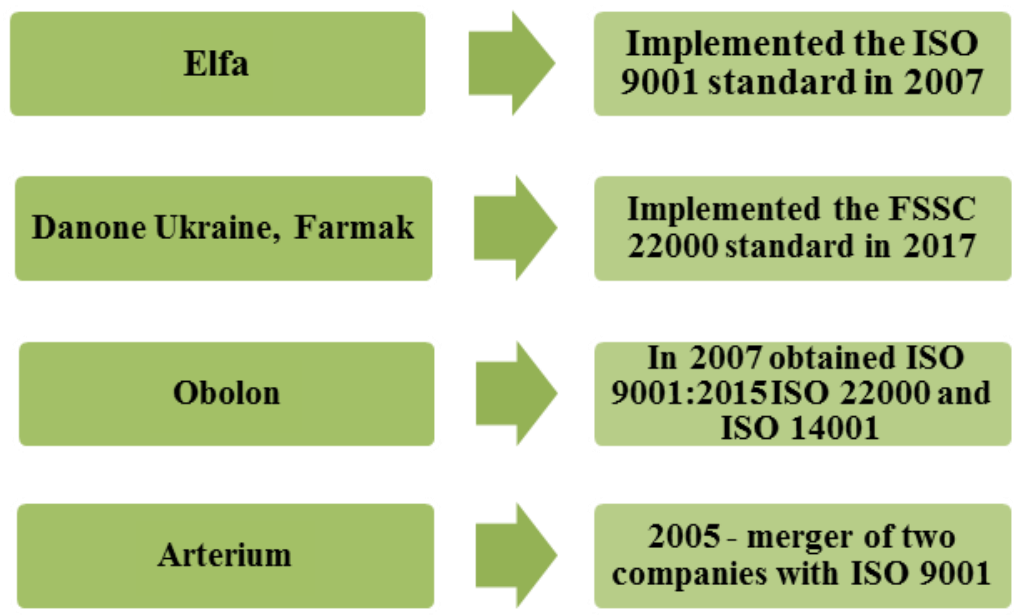

\section{Began exports to CIS countries in 2008}

Obtained a permition and started exporting to EU countries

In 2010 it was presented in 3 countries of the world

Start of export of medicines since 2008

Figure 4 - Economic results from the standardization of Ukrainian manufacturing companies

Source: authors

Thus, the standardization of the enterprise and obtaining an international certificate of quality is an opportunity for the enterprise to enter the international market. This is one of the main requirements for working with foreign customers. The export indicators of the companies analyzed at this stage depend on the foreign economic policy, but each of them is audited every 3 years for compliance with the requirements of the standard. The loss of one of the standards can be a significant reason for the deterioration of positions in the international market.

The analysis showed that the implementation of quality standards can affect indirectly the level of international competitiveness of manufacturing enterprises, determining the possibility of increasing their export activities. Schematically, the relationship between the improvement of the management system and the international competitiveness of enterprises can be represented in the form of an enlarged scheme (Fig. 5). 


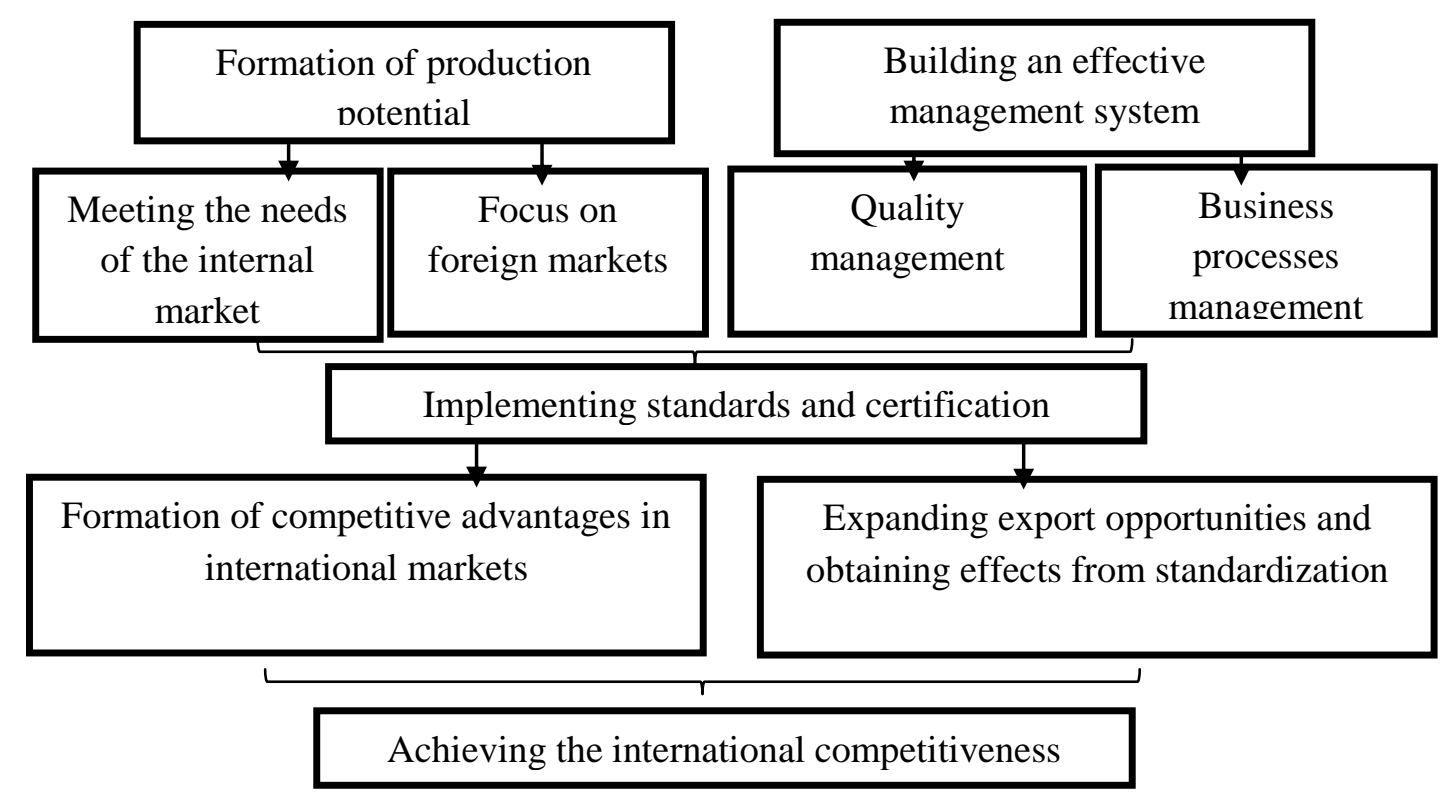

Figure 5 - The impact of standardization on the international competitiveness of the enterprise

Source: authors

It should be noted that the implementation of ISO standards provides an opportunity to form long-term competitive advantages, which is very important to ensure the strategic competitiveness of manufacturing enterprises.

Conclusion. According to the results of the study, the authors concluded that by improving the quality management system and standardization enterprise can get additional sources of competitive advantage. Standardization indirectly affects the increase of competitive position in international markets by increasing export potential and ensuring compliance of production with the requirements of foreign customers. The study shows the relationship between the implementation of ISO standards in enterprises and obtaining additional opportunities for export to foreign markets by analyzing examples of the successful standardization in Ukraine.

An element of the novelty of the study is the specification of the meaningful relationship between the process of standardization and the creation of long-term competitive advantages of manufacturing enterprises, which considers the intensification of export activities of enterprises in terms of uncertainty.

A promising area of further research is an assessing the economic efficiency of standardization as a tool to increase the international competitiveness of manufacturing enterprises in the period of recovery of the world economy after the covid pandemic. 


\section{References:}

1. Verkhovna Rada of Ukraine (2014). About standardization: Low of Ukraine. Vidomosti Verkhovnoyi Rady (VVR), Is. 31, p.1058.

2. Yanovytska G., Verhola U. (2015). Standardization and certification as agents for safety and quality provision of goods, works, services. The Scientific Bulletin of Lviv State University of Internal Affairs, Vol. 2, pp.97-107.

3. Byba V., Tenytska N. (2017). Quality of production as factor of competitiveness of the enterprise. Economy and Society [Ekonomika i Suspilstvo], Vol. 12, pp. 171-176.

4. Pochynok K. (2011). Standardization as one of the factors of providing the competitiveness of products. Proceedings of the 5th International Scientific and Practical Conference "Theory and practice of economic analysis: current situation, actual problems, and development prospects" [Teoriya i praktyka ekonomichnoho analizu: suchasnyy stan, aktualni problemy ta perspektyvy rozvytku], September 29 October 1, 2011, Ternopil: Ternopil national economic university, pp. 190-191.

5. Dobrin C. et al. (2015). Quality: a determinant factor of competitiveness - the evolution of iso certifications for management systems. Proceedings of the 9th International management conference "Management and innovation for competitive advantage”, November 5th-6th, Romania, Bucharest, pp. 1062-1073.

6. Arvius Ch. et al. (2010). Standardization for a competitive and innovative Europe: a vision for 2020: report of the expert panel for the review of the european standardization $\quad$ system. $45 \quad$ p. http://www.anec.eu/attachments/Definitive\%20EXPRESS\%20report.pdf.

7. Bondar O. (2013). Standardization and certification as methods of product quality assurance. Scientific Herald of NULES of Ukraine.Series: Economy, agrarian management, business [Naukovyi Visnyk NUBiP Ukrainy. Seriia Ekonomika Ahrarnyi Menedzhment Biznes], Vol 181, pp. 138-144.

8. Kalyta P. (2018). "Deficit economy" syndrome. Standardization, Certification, Quality [Standartyzatsiia, sertyfikatsiia, yakist], Vol. 1 (108), pp. 17-21.

9. Harasym Yu. (2015). Standardization and certification national system analysis under Ukraine-European Union association agreement. Foreign trade: economics, finance, law [Zovnishnia torhivlia: ekonomika, finansy, pravo], Vol. 3 (80), pp. 58-65.

10. Golinka I. (2011). The role and place of standardization in supporting innovation in the knowledge economy. Project management and production development [Upravlinnia proektamy ta rozvytok vyrobnytstva], Vol. 1 (37), pp. 78-86.

11. Naidonova M. (2009). International standardization as a factor of increasing the competitiveness of national production. Bulletin of Transport Economics and Industry [Visnyk ekonomiky transportu i promyslovosti], Vol. 25, pp. 128-131.

12. Endo N. (2020). Bringing business an ultimate benefits. ISOfocus. Vol 139. p. 2-3. URL: https://www.iso.org/files/live/sites/isoorg/files/news/magazine/ISOfocus\%20(2013NOW)/en/2020/ISOfocus_139/ISOfocus_139_en.pdf.

13. State statistics service of Ukraine (2019). Number of business entities by types of economic activity in 2010-2018: statistics. URL: http://www.ukrstat.gov.ua/operativ /operativ2018/fin/pssg/pssg_u/ksg_ek_2010_2018_u.xlsx.

14. State statistics service of Ukraine (2020). Volume of industrial products (goods, services) sold in 2010-2019: statistics. URL: http://www.ukrstat.gov.ua/operativ/ operativ2013/pr/orp_rik/orp_rik_e.htm. 
15. State statistics service of Ukraine (2020). Indices of industrial production in Ukraine for 2015-2020: statistics. URL: http://www.ukrstat.gov.ua/operativ/operativ 2014/pr/ipp/ipp_e/ippe14.htm.

16. State statistics service of Ukraine (2020). Dynamics of the geographical structure of foreign trade in goods (1996-2019): statistics. URL: http://www.ukrstat.gov.ua/operativ/ operativ2005/zd/zd_rik/zd_e/gs_rik_e.html.

17. Us I. (2020). On foreign trade in Ukrainian goods in May 2020: report. National Institute for Strategic Studies. 5 p. URL: https://niss.gov.ua/sites/default/files/202006/zovnishnya-torgivlya-ukrainy.pdf.

18. International Monetary Fund (2020). World economic outlook update. 20 p. URL: https://www.imf.org/ /media/Files/Publications/WEO/2020/Update/June/English/WE OENG202006.ashx?la=en.

19. Keen R. (2019). Is ISO 9001 Global? (Including Statistics). URL: https://www.iso9001-checklist.co.uk/is-ISO-9001-global.htm.

20. The official website of Obolon. URL: https://obolon.ua.

21. Interfax-Ukraine (2020). The share of exports in the sales structure of "Farmak" in 2019 exceeded 22\%. URL: https://interfax.com.ua/news/economic/643201.html.

22. The official website of Farmak JSC. URL: https://farmak.ua/ru/about/.

23. The official website of Elfa. URL: http://www.elfa.ua/company/achieve/.

24. The official website of Danon-Ukraine. URL: http://danone.ua/\#danone.

25. The official website of Arterium Corporation. URL: https://www.arterium.ua.

УДК: 657:004

JEL classification: $M 11$, M15

Курган Н. В.

канд. екон. наук, дочент

ORCID ID: 0000-0003-1155-6859

Харківський національний економічний університет імені Семена Кузнеця

\section{ОБГРУНТУВАННЯ ВИБОРУ ЕRР-РІШЕННЯ ДЛЯ ЦИФРОВІЗАЦІЇ ОБЛІКУ, АНАЛІЗУ ТА УПРАВЛІННЯ НА ПІДПРИЕМСТВІ УКРАЇНИ}

\section{JUSTIFICATION OF THE CHOICE OF ERP-SOLUTION FOR DIGITALIZATION OF ACCOUNTING, ANALYSIS AND MANAGEMENT AT THE ENTERPRISE OF UKRAINE}

В наш час глобальних прочесів інтеграції бізнесу з IT-середовищем, розвитку Інтернет-торгівлі, суиільної комп'ютеризачії документообігу та інформаційних потоків, будь-яке підприємство Украӥни, незалежно від розміру й масштабів господарювання, має запит на розбудову ЕRP-системи для модернізації управління та відповідного обліково-аналітичного забезпечення. В умовах сьогодення, конкурентні переваги, рентабельність та прибутковість діяльності досягаються на засадах інтенсивного розвитку з елементами інноваційності. Керівництво має організувати гнучке, мобільне, ефективне управління діяльністю підприємства, яке б забезпечувало рачіональне та економне використання усіх залучених до бізнесу 